2. To: (Receiving Organization);

Distribution

5. Proj./Prog./Dept./Div.:

106029 105-AN Corrosion Probe

8. Originator Remarks:

TTP\# RLO-8-WT-21.

Informal . design review per HWF-PR 0.233 by C.E. Jensen

11. Receiver Remarks:

11A. Design Baseline Document?

OYes ONo

Design of third-generation corrosion monitoring system.
This document satisfies the requirements of Milestone B1 of FY 1999

\section{Related EDT No: \\ 625706 \\ 7. Purchase Order No.: \\ $\mathrm{N} / \mathrm{A}$ \\ 9. Equip./Component No.: \\ $\mathrm{N} / \mathrm{A}$}

10. System/Bldg./Facility:

$\mathrm{N} / \mathrm{A}$

12. Major Assm. Dwg. No.:

$\mathrm{N} / \mathrm{A}$

13. Permit/Permit Application No.:

N/A

14. Required Response Date:

$\mathrm{N} / \mathrm{A}$

15

DATA TRANSMITTED

(A)

Item

(B) Document/Drawing No.

(C) Sheet
No.

(E) Title or Description of Data Transmitted

(F)

/A

(G)

G) (H)

(I)

Approval Reason Origi- Receiv-

Desig- for Trans- nator
nator

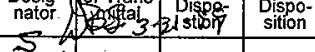

1

1 HNE-4285

Design of Multi-Function

Hanford Tank Corrosion

Monitoring system

\begin{tabular}{|c|c|c|c|}
\hline$\widehat{A}+\widetilde{A}$ & 2 & 1 & $I$ \\
\hline & & & \\
\hline & & & \\
\hline & & & \\
\hline & & & \\
\hline & & & \\
\hline
\end{tabular}

16.

KEY

\begin{tabular}{|c|c|c|c|c|}
\hline Approval Designator (F). & \multicolumn{2}{|c|}{ Reason for Transmittal (G) } & \multicolumn{2}{|c|}{ Disposition $(\mathrm{H}) \&(\mathrm{l})$} \\
\hline $\begin{array}{l}\text { E,S, Q, D OR N/A } \\
\text { (See WHC-CM-3-5, } \\
\text { Sec. 12.7) }\end{array}$ & $\begin{array}{l}\text { 1. Approval } \\
\text { 2. Release } \\
\text { 3. Information }\end{array}$ & $\begin{array}{l}\text { 4. Review } \\
\text { 5. Post-Review } \\
6 \text {. Dist. (Receipt Acknow. Required) }\end{array}$ & $\begin{array}{l}\text { 1. Approved } \\
\text { 2. Approved w/comment } \\
\text { 3. Disapproved w/comment }\end{array}$ & $\begin{array}{l}\text { 4. Reviewed no/comment } \\
\text { 5. Reviewed w/comment } \\
6 \text {. Receipt acknowledged }\end{array}$ \\
\hline
\end{tabular}
17.

SIGNATURE/DISTRIBUTION

(See Approval Designator for required signatures)

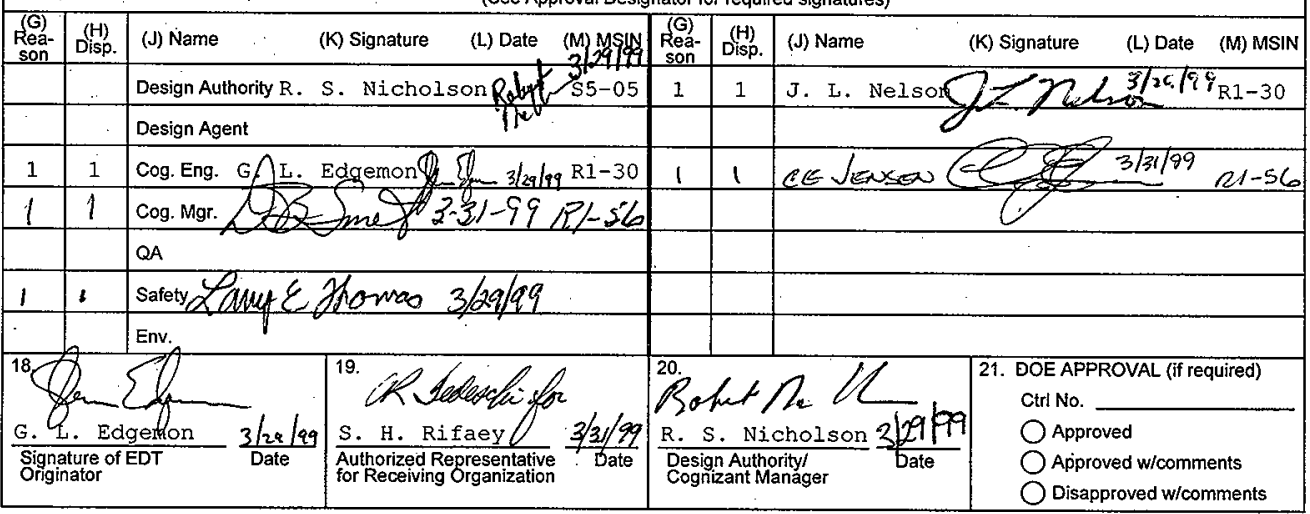




\title{
Design of Multi-Function Hanford Tank Corrosion Monitoring System
}

\author{
G. L. Edgemon \\ Lockheed Martin Hanford Corporation \\ Richland, WA 99352 \\ U.S. Department of Energy Contract DE-AC06-96RL13200

$\begin{array}{lll}\text { EDT/ECN: } & 625706 & \text { UC: } 2030 \\ \text { Org Code: } 74711 & \text { Charge Code: } 106029 \\ \text { B\&R Code: } & \text { EW4010000 } & \text { Total Pages: } 13\end{array}$

Key Words: corrosion probe, multi-function probe, electrochemical noise Abstract: Design description for Milestone B1 of FY 1999 TTP\# RL0-8-WT-21.

TRADEMARK DISCLAIMER. Reference herein to any specific commercial product, process, or service by trade name, trademark, manufacturer, or otherwise, does not necessarily constitute or imply its endorsement, recommendation, or favoring by the United States Government or any agency thereof or its contractors or subcontractors.

Printed in the United States of America. To obtain copies of this document, contact: Document Control Services, P.O. Box 950, Mailstop H6-08, Richland WA 99352, Phone (509) 372-2420; Fax (509) 376-4989.
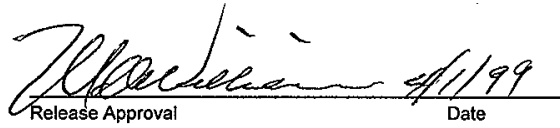

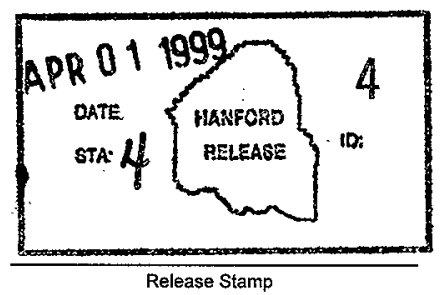




\section{Introduction and Background}

The Hanford Site has 177 underground waste tanks that store approximately 253 million liters of radioactive waste from 50 years of plutonium production [1]. Twenty-eight (28) tanks have a double shell and are constructed of welded ASTM A537-Class 1 (UNS K02400), ASTM A515Grade 60 (UNS K02401), or ASTM A516-Grade 60 (UNS K02100) material. The inner tanks of the double-shell tanks (DSTs) were stress relieved following fabrication. One hundred and fortynine (149) tanks have a single shell, also constructed of welded mild steel, but not stress relieved following fabrication. Tank waste is in liquid, solid, and sludge forms. Tanks also contain a vapor space above the solid and liquid waste regions. The composition of the waste varies from tank to tank but generally has a high $\mathrm{pH}(>12)$ and contains sodium nitrate, sodium hydroxide, sodium nitrite, and other minor radioactive constituents resulting from plutonium separation processes [1-4]. Leaks began to appear in the single-shell tanks shortly after the introduction of nitrate-based wastes in the 1950s. Leaks are now confirmed or suspected to be present in a significant number of single-shell tanks [1]. The probable modes of corrosion failures are reported as nitrate stress corrosion cracking (SCC) and pitting [2].

Previous efforts to monitor internal corrosion of waste tank systems have included linear polarization resistance (LPR) and electrical resistance techniques [5-6]. These techniques are most effective for monitoring uniform corrosion, but are not well suited for detection of localized corrosion (pitting and SCC). The Savannah River Site (SRS) investigated the characterization of electrochemical noise (EN) for monitoring waste tank corrosion in 1993, but the tests were not conclusive [7]. The SRS effort has recently been revived and additional testing is underway.

For many years, EN has been observed during corrosion and other electrochemical reactions, and the phenomenon is well established [8-19]. Typically, EN consists of low frequency $(<1 \mathrm{~Hz})$ and small amplitude signals that are spontaneously generated by electrochemical reactions occurring at corroding or other surfaces [20]. Laboratory studies and recent reports on field applications have reported that EN analysis is well suited for monitoring and identifying the onset of localized corrosion, and for measuring uniform corrosion rates [14-26]. A two year laboratory study was started at Hanford in 1995 to provide a technical basis for using EN in Hanford nuclear waste tanks [27]. Based on this study, a prototype system was constructed and deployed in DST 241-AZ-101 in August, 1996 [28]. Based on the successful demonstration of this prototype for more than a year, a first-generation full-scale system was designed and installed into DST 241-AN-107 in September 1997 [29]. A second-generation full-scale system similar to the 241-AN-107 system was design, fabricated and installed in 241-AN-102 in August 1998 [30]. This document summarizes the design and operational requirements of the thirdgeneration full-scale system scheduled for deployment into 241-AN-105 in fiscal year 1999 as required by Milestone Number B1 of TTP RL0-8-WT- 21 .

Like most EN based corrosion-monitoring systems, the 241-AN-105 system is designed to measure instantaneous fluctuations in corrosion current and potential between three nominally identical mild steel electrodes (a working, a counter, and a pseudo-reference electrode) immersed in the waste. The fluctuations in current and potential are caused by corrosion of the electrodes. It has been shown that each type of corrosion phenomenon presents a unique relationship between corrosion current and potential transients in the temporal data [8-29]. 
The 241-AN-105 system is a multi-function instrument and contains several features not seen on previous Hanford systems. In addition to the eight channels of corrosion monitoring electrodes incorporated on previous probes, the new system is also fitted with an array of 22 thermocouples, a verification thermocouple, a tank waste high level detector, ports for pressure/gas sampling and a set of strain gauges to monitor the effects of tank operations on the downhole instrumentation. These features add a great deal of functionality to the probe, provide for a better understanding of the relationship between corrosion and other tank operating parameters, and optimize the use of the riser that houses the probe in the tank.

\section{System Design}

Details of the probe design are shown in the drawings attached at the end of this document. The following are the primary design features of the tank-intrusive portion of the 241-AN-105 corrosion monitoring system:

- The probe is fabricated from materials capable of providing at least five years of service.

- The maximum diameter of the probe fits through $10.2-\mathrm{cm}(4.0 \mathrm{in}$.) diameter riser.

- The probe design facilitates decontamination by minimizing areas of liquid retention.

- All materials are capable of withstanding temperature ranges up to $100^{\circ} \mathrm{C}$.

- All materials are capable of withstanding liquid phase $\mathrm{pH}$ ranges from 7 to 14 .

- All materials are be capable of withstanding radiation levels up to $1000 \mathrm{R} / \mathrm{hr}$.

- Probe design has passed site structural analysis for mixer pump operation [31].

- Probe design has passed site standard seismic analysis for non-safety class equipment [32].

- Conductor/feed-through connections shall be angled to withstand probe flexure.

- Gasket seating surfaces utilize O-rings instead of a washer type gasket for improved seal.

- Probe incorporates eight channels of EN electrodes.

- Four channels of EN electrodes utilize $44 \mathrm{~cm}^{2} \mathrm{C}$-rings.

- One electrode of each C-ring array is pre-cracked and strained prior to immersion.

- Four channels of EN electrodes utilize $25 \mathrm{~cm}^{2}$ bullet shaped electrodes.

- EN electrodes are fabricated from ASTM A-537 CL 1 mild steel heat treated to match tank.

- Electrodes are electrically isolated from probe through the use of glass-lined feed throughs.

- Probe design contains an equally spaced array of 22 thermocouples.

- Probe design contains an adjustable verification thermocouple.

- Probe design contains a tank waste high level detector.

- Probe design contains three ports for pressure/gas sampling.

- Probe design contains one set of strain gauges to monitor probe flexure if flexure occurs.

- Probe utilizes an adjustable collar to allow depth adjustment of probe during installation.

- Probe body serves as grounded shield to reduce unwanted interference in the data.

The following are the primary design features of the software/hardware used to collect data from the tank-intrusive portion of the probe:

- Current and voltage EN data is collected in an automated, user configurable fashion.

- Data is recorded at a rate of one measurement every other second. 
- System simultaneously monitors eight channels of EN electrodes.

- System is capable of periodically conducting LPR scans.

- System is housed in a climate controlled enclosure adjacent to the riser containing the probe.

- System uses wireless Ethernet links to send data to Hanford Local Area Network.

- System uses commercial remote access software to allow remote command and control.

- Above ground wiring uses driven shields to reduce external electrostatic noise in the data.

- MTL Model 755-AC shunt-diode type intrinsic safety barriers are used on all conductors.

- The operating software is compatible with site standard desktop PCs.

- All data is stored in ODBC and SQL compatible databases.

The tank-intrusive portion of the system is manufactured by Hiline Engineering and Fabrication in Richland, Washington. The data collection software/hardware system is an Amulet system manufactured by Corrosion \& Condition Control, Ltd. The design of the corrosion monitoring system has been reviewed and approved by the Hanford Site Flammable Gas Equipment Advisory Board as documented in report FGEAB-97-040, Rev. 2 [33].

\section{Conclusions}

A multi-function corrosion monitoring system has been designed for installation into DST 241AN-105 at the Hanford Site in fiscal year 1999. The 241-AN-105 system is the third-generation corrosion monitoring system described by TTP RL0-8-WT-21. Improvements and upgrades from the second-generation system (installed in 241-AN-102) that have been incorporated into the third-generation system include:

- Gasket seating surfaces utilize O-rings instead of a washer type gasket for improved seal.

- Probe design contains an equally spaced array of 22 thermocouples.

- Probe design contains an adjustable verification thermocouple.

- Probe design contains three ports for pressure/gas sampling.

- Probe design contains one set of strain gauges to monitor probe flexure if flexure occurs.

- Probe utilizes an adjustable collar to allow depth adjustment of probe during installation.

- System is capable of periodically conducting LPR scans.

- System is housed in a climate controlled enclosure adjacent to the riser containing the probe.

- System uses wireless Ethernet links to send data to Hanford Local Area Network.

- System uses commercial remote access software to allow remote command and control.

- Above ground wiring uses driven shields to reduce external electrostatic noise in the data.

These new design features have transformed what was primarily a second-generation corrosion monitoring system into a multi-function tank monitoring system that adds a great deal of functionality to the probe, provides for a better understanding of the relationship between corrosion and other tank operating parameters, and optimizes the use of the riser that houses the probe in the tank 


\section{References}

[1] P.C. Ohl, J.D. Thomson, and F.R. Vollert, Corrosion Considerations for Life Management of Hanford High Level Waste Tanks, CORROSION/94, paper no. 142, (Houston, TX: NACE International, 1994).

[2] D.C. Lini, Compilation of Hanford Corrosion Studies, Atlantic Richfield Hanford Company Report, ARH-ST-111, UC-70, July, 1975.

[3] J.R. Divine, W.M. Bowen, D.B. Mackey, D.J. Bates, and, K.H. Pool, Prediction Equations for Corrosion Rates of A537 and A516 Steels in Double Shell Slurry, Future PUREX, and Hanford Facilities Wastes, Pacific Northwest Laboratory Report, PNL5488, June, 1985.

[4] W.C Carlos, Recommendations for Erosion/Corrosion Allowance for Multi-Function Waste Tank Facility Tanks, CORROSION/95, paper no. 449, (Houston, TX: NACE International, 1995).

[5] J.L. Nelson, Hanford DST Corrosion Monitoring Instrument Tree, CORROSION/95, paper no. 440, (Houston, TX: NACE International, 1995).

[6] R.K. Shukla, A.J. Perkins, P.M. Bourgeois, R.J. Jaramins, W.G. Secen, and, D.J. Stroud, Corrosion Monitoring of High Level Waste Storage Tank 8-D2 at the West Valley Demonstration Project, CORROSION/94, paper no. 121, (Houston, TX: NACE International, 1994).

[7] J.I. Mickalonis, R.J. Jacko, G.P. Quirk, and D.A. Eden, in: Proc. First Int. Symposium on Electrochemical Noise Measurements for Corrosion Applications, ASTM STP 1277, eds. J.R. Kearns, J.R. Scully, P.R. Roberge, D.L. Reichert, and J.L. Dawson, (American Society for Testing and Materials, Philadelphia, PA, 1996) p. 201.

[8] T. Haygard and J. R. Williams, Trans. Farad. Soc. 57, (1961): p. 2288.

[9] P. Bindra, et al., Discussions of Faraday Soc. 56, (1974): p. 189.

[10] M. Fleischmann, et al., Surface Science 100-101, (1980): p. 583.

[11] G.J. Bignold and M. Fleischmann, Electrochemical Acta 19, (1974): p. 363.

[12] E. Budevski, et al., Electrochemical Acta 28, (1983): p. 925.

[13] G. Blanc, et al., Electrochemical Acta 23, (1978): p. 337.

[14] K. Hladky and J. L. Dawson, Corrosion Science 22, (1982): p. 231. 
[15] D.A. Eden, J.L. Dawson, and D.G. John, U.K. Patent Application 861158, May 1986, U.S. Patent 5139627.

[16] K. Hladky, European Patent 084404A3, U.S. Patent 455709, Canadian Patent 418938.

[17] U. Bertocci, Electrochemical Noise Analysis and Its Application to Corrosion, CORROSION/89, paper no. 24, (Houston, TX: NACE International, 1989).

[18] J.L. Dawson, D.M. Farrell, P.J. Aylott, and K. Hladky, Corrosion Monitoring Using Electrochemical Noise Measurements, CORROSION/89, paper no. 31, (Houston, TX: NACE International, 1989).

[19] D.A. Eden, A. N. Rothwell, and J.L. Dawson, "Electrochemical Noise for Detection of Susceptibility to Stress Corrosion Cracking, CORROSION/91, paper no. 444, (Houston, TX: NACE International, 1991).

[20] D.M. Farrell, Industrial Corrosion 9, (1991): p. 7.

[21] A.N. Rothwell, T.G. Walsh, and W.M. Cox, On Line Corrosion Investigation and Surveillance - Chemical Plant Case Studies, CORROSION/91, paper no. 170, (Houston, TX: NACE International, 1991).

[22] J.L. Dawson, et al., On-line Monitoring of Continuous Process Plants, ed. D. Butcher, (Ellis Horwood, NY, 1983).

[23] D.M. Farrell, W.M. Cox, and D. Gearey, Multi-System Corrosion Monitoring in a Cyclic Reheat Test Facility; Phase 1, Electric Power Research Institute Report, CS-5776, 1988.

[24] D.M. Farrell, W.M. Cox and D. Gearey, Multi-System Corrosion Monitoring in FGD Systems; Phase 2, Electric Power Research Institute Report, CS-5734, 1988.

[25] B.C. Syrett and W.M. Cox, in: Proc. First Int. Symposium on Electrochemical Noise Measurements for Corrosion Applications, ASTM STP 1277, eds. J.R. Kearns, J.R. Scully, P.R. Roberge, D.L. Reichert, and J.L. Dawson, (American Society for Testing and Materials, Philadelphia, PA, 1996) p. 173.

[26] C.A. Lotto and R.A. Cottis, Corrosion 45, (1989): p. 136.

[27] G.L. Edgemon and G.E.C. Bell, Technical Basis for Electrochemical Noise Based Corrosion Monitoring of Underground Nuclear Waste Storage Tanks, Westinghouse Hanford Company Report, WHC-SD-WM-TI-772, November, 1996.

[28] G.L. Edgemon, J.L. Nelson, P.C. Ohl, and G.E.C. Bell, Hanford Prototype Corrosion Probe Operational Experience, CORROSION/97, paper no. 97124, (Houston, TX: NACE International, 1997). 
[29] G.L. Edgemon, J.L. Nelson, and G.E.C. Bell, Design of an Electrochemical Noise Based Corrosion Monitoring Probe for High Level Nuclear Waste Storage Tanks, CORROSION/98, paper no. 98175, (Houston, TX: NACE International, 1998).

[30] G.L. Edgemon and J. L. Nelson, Design of Second-Generation Corrosion Monitoring Probe, Lockheed Martin Hanford Company Report, HNF-2517, Rev. 0, April, 1998.

[31] H. P. Shrivastava, Structural Evaluation of Second Generation Double Shell Tank Corrosion Probe Tree, Lockheed Martin Hanford Company Report, HNF-SD-WM-CN090, Rev. 0, June, 1997.

[32] H. S. Ziada, Analysis of the Effects of Corrosion Probe on Riser 241-AN-102-WST-16 During Seismic Event, Numatec Hanford Company Report, HNF-3162, Rev. 0, November, 1998.

[33] C. C. Scaief III, Flammable Gas Equipment Advisory Board Interpretation/ Recommendation Report - Corrosion Monitoring System, FGEAB-97-040. Rev. 2, Lockheed Martin Hanford Corporation, May, 1998. 
GENERAL NOTES: (unLEss Omerermse seccireo)

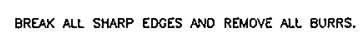

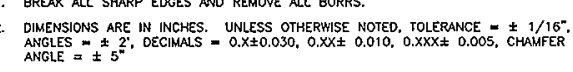

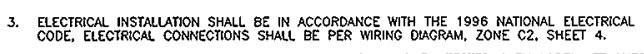

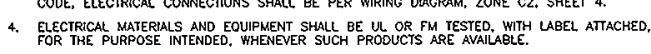

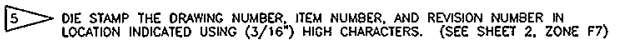

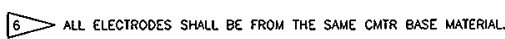

7 SLLVER SOLLER MEM NO 26 (CARLE) TO TIEM NO 23 (SEAL PIN) AT ASSEMELY. (24 PL)

8. WELD AND INSPECT PER ANSI 831.3

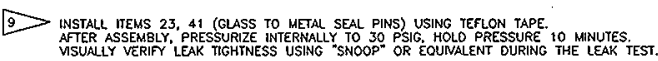

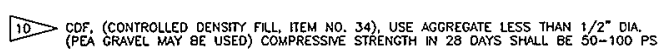

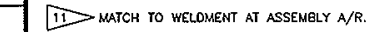

12. WACHMEO SURFACES TO BE 125 OR BETTER PER ANSI 846 .

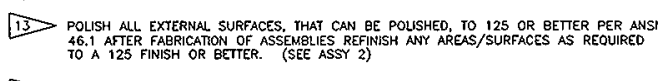

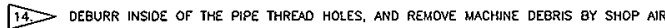
(15) DELERo

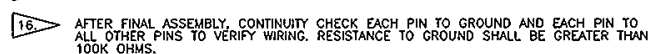

17. EVENUY SPACE 22 TTERMOCOUPLES TO ENO OF PROBE.

18. DIANGRKCAL CLEAPANCE BETIEEN ROD ANO BORE $=0.005$ MaX.

19 OIMENSION TO CENTER OF ELECTROOR FOR ELEVATION ATER ASSEUELY. ADJUST WELDEENT A/R

20.7 OIMENSION TO CENTER OF CEMTERLINE OF 20 \& SURFACE OF 27.

211. PROTECT STRAN GAUGES WITH COVER.

DIMENSIONAL SCHEDULE (SEE SHEET $2 \&$ \&)

\begin{tabular}{|c|c|c|c|c|c|c|c|c|c|c|c|c|}
\hline & \multirow[t]{2}{*}{ A } & \multirow{2}{*}{$\frac{B}{19-r^{\prime}}$} & \multirow{2}{*}{\begin{tabular}{|c|}
$C$ \\
$20^{\prime}-43 / 4^{4}$ \\
\end{tabular}} & \multirow{2}{*}{$\frac{D}{27^{\prime}-11^{\prime}}$} & \multirow{2}{*}{$\frac{E}{41^{\prime}-2^{*}}$} & \multirow{2}{*}{$\frac{F}{54^{4}-43 / 4^{*}}$} & \multirow{2}{*}{$\frac{G}{55^{\prime}-11^{\prime \prime}}$} & \multirow{2}{*}{$\frac{H}{2 t^{\prime}-8^{-}}$} & \multirow[t]{2}{*}{$J$} & \multirow[t]{2}{*}{$\mathrm{K}$} & \multirow[t]{2}{*}{ L } \\
\hline \multirow{2}{*}{-010} & ASSY NO & & & & & & & & & & & \\
\hline & \begin{tabular}{|l|} 
INCHES \\
\end{tabular} & & (235) & $(2443 / 4)$ & (335) & (494) & $(6523 / 4)$ & (677) & ${ }_{(260)}$ & & & \\
\hline & & & & & & & & & & & & \\
\hline
\end{tabular}

OIMENSIONAL SCHEDULE (THERMOCOUPLE LENGTH)

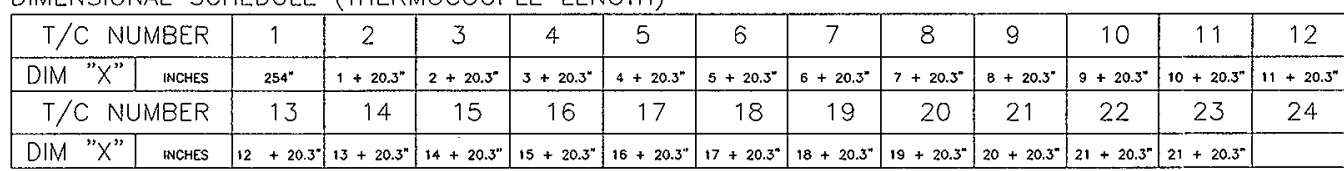

12

$1+3=-4$

s

1

$\perp$

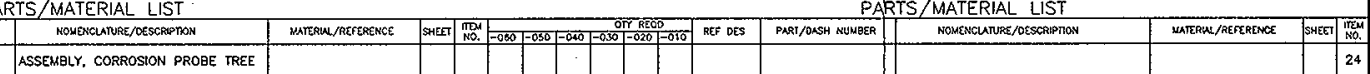

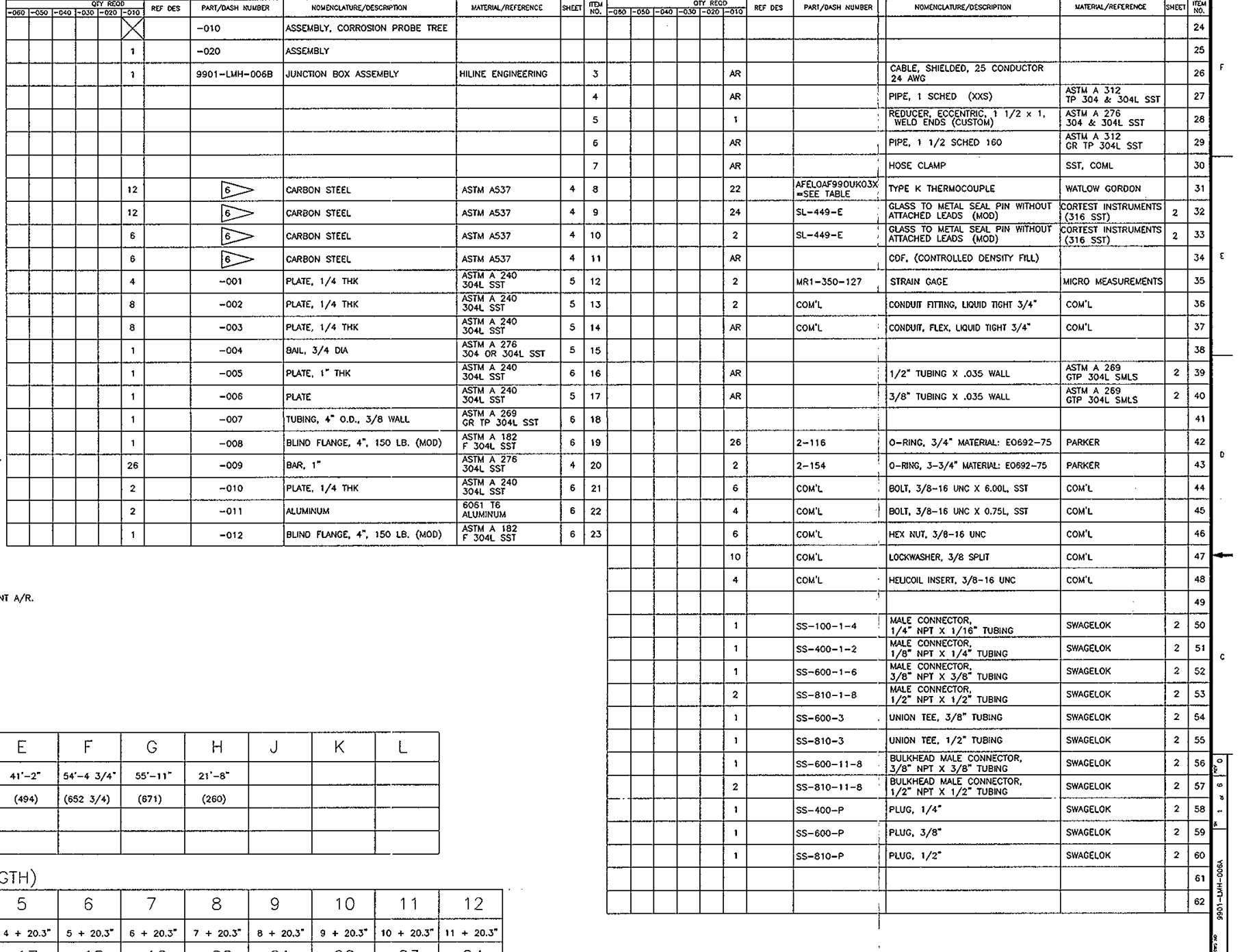

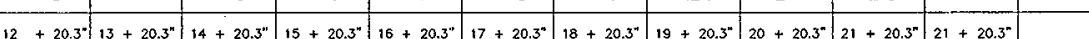

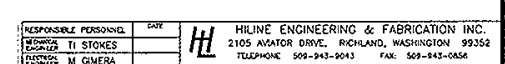

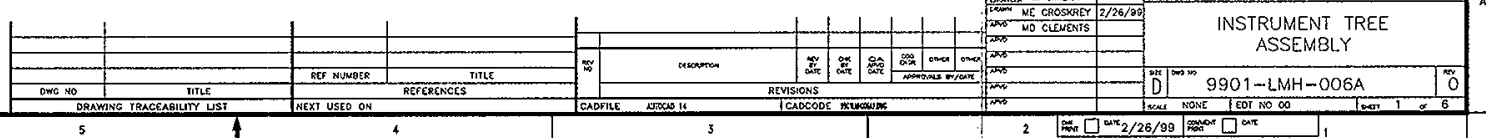




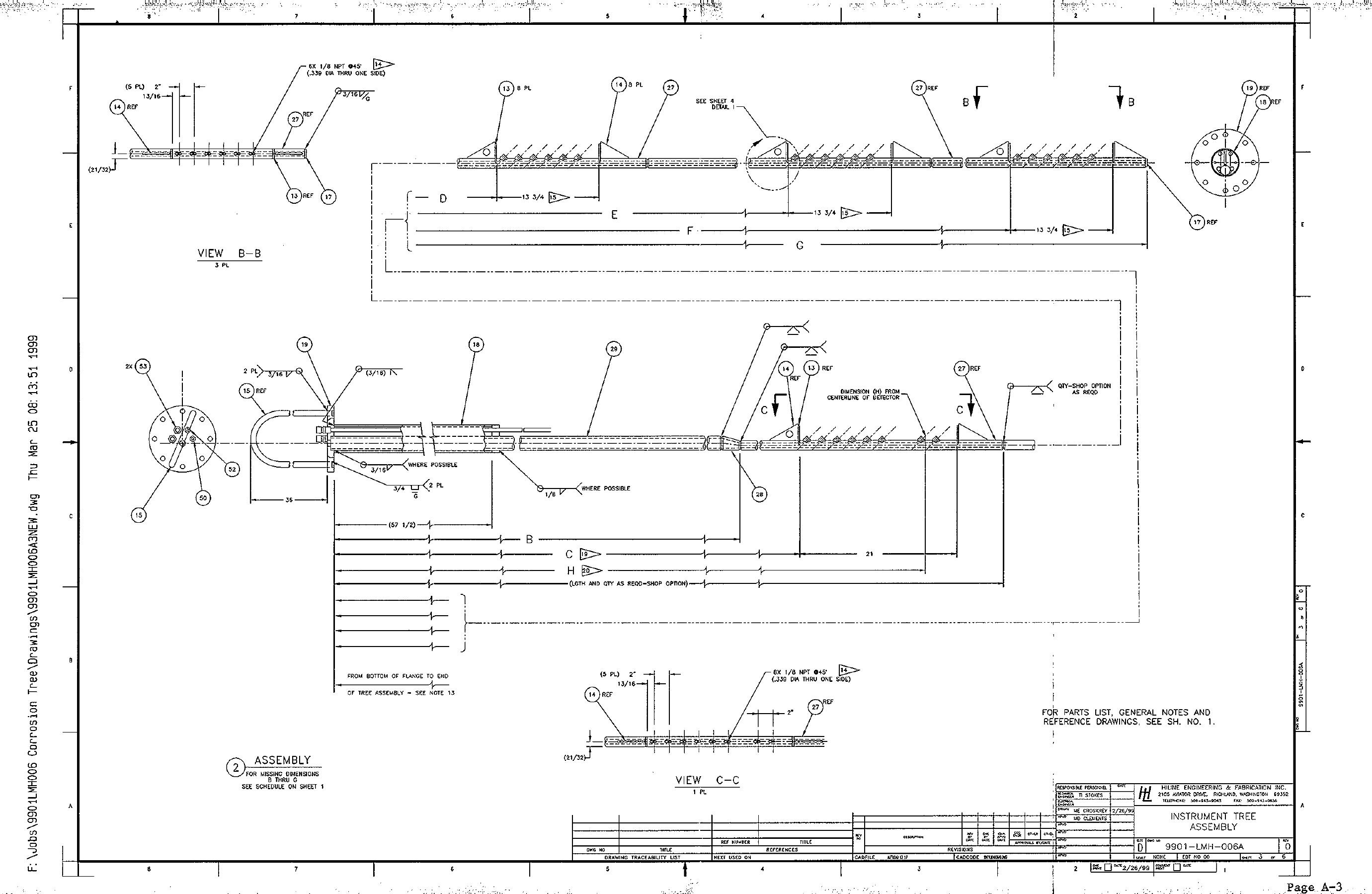




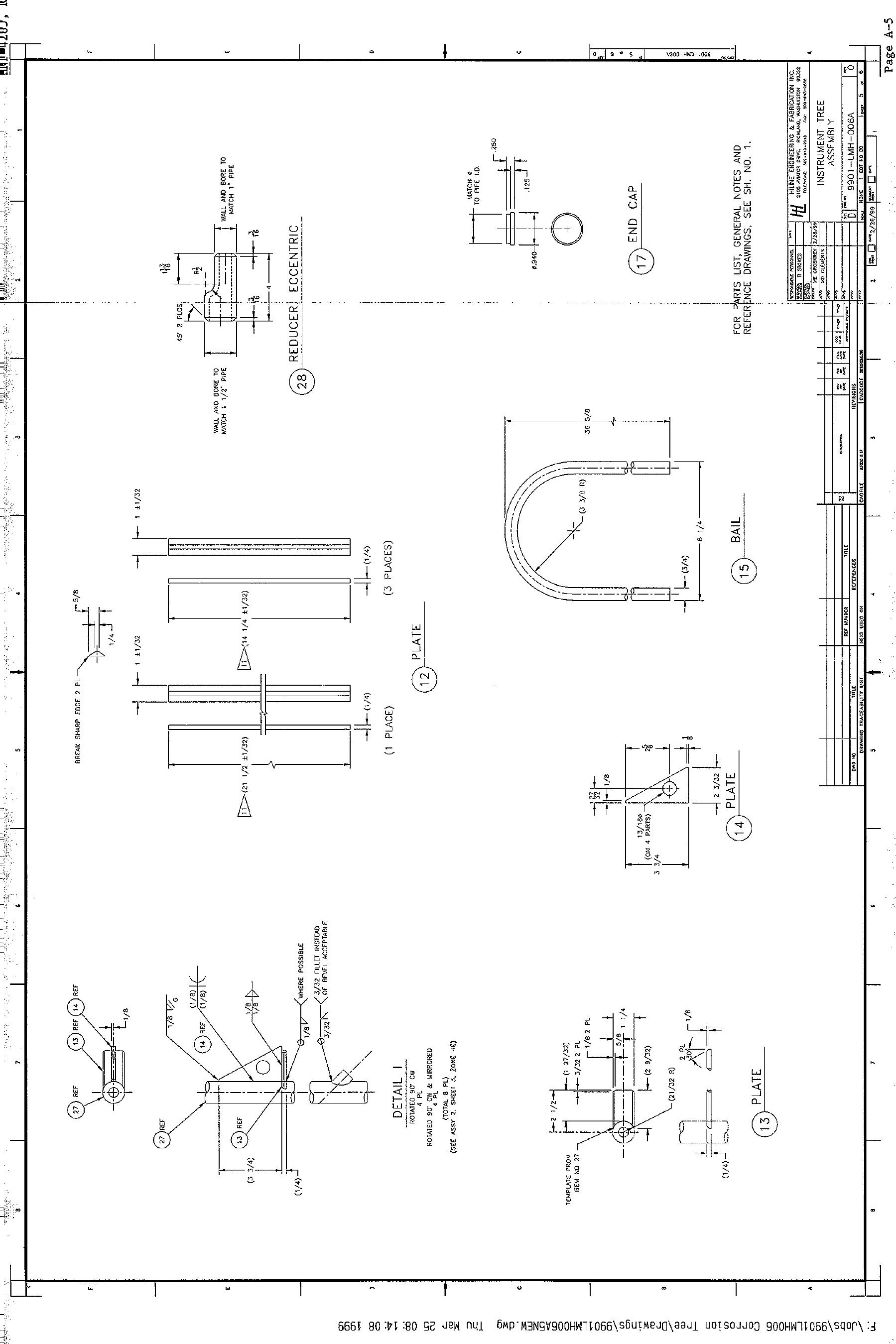




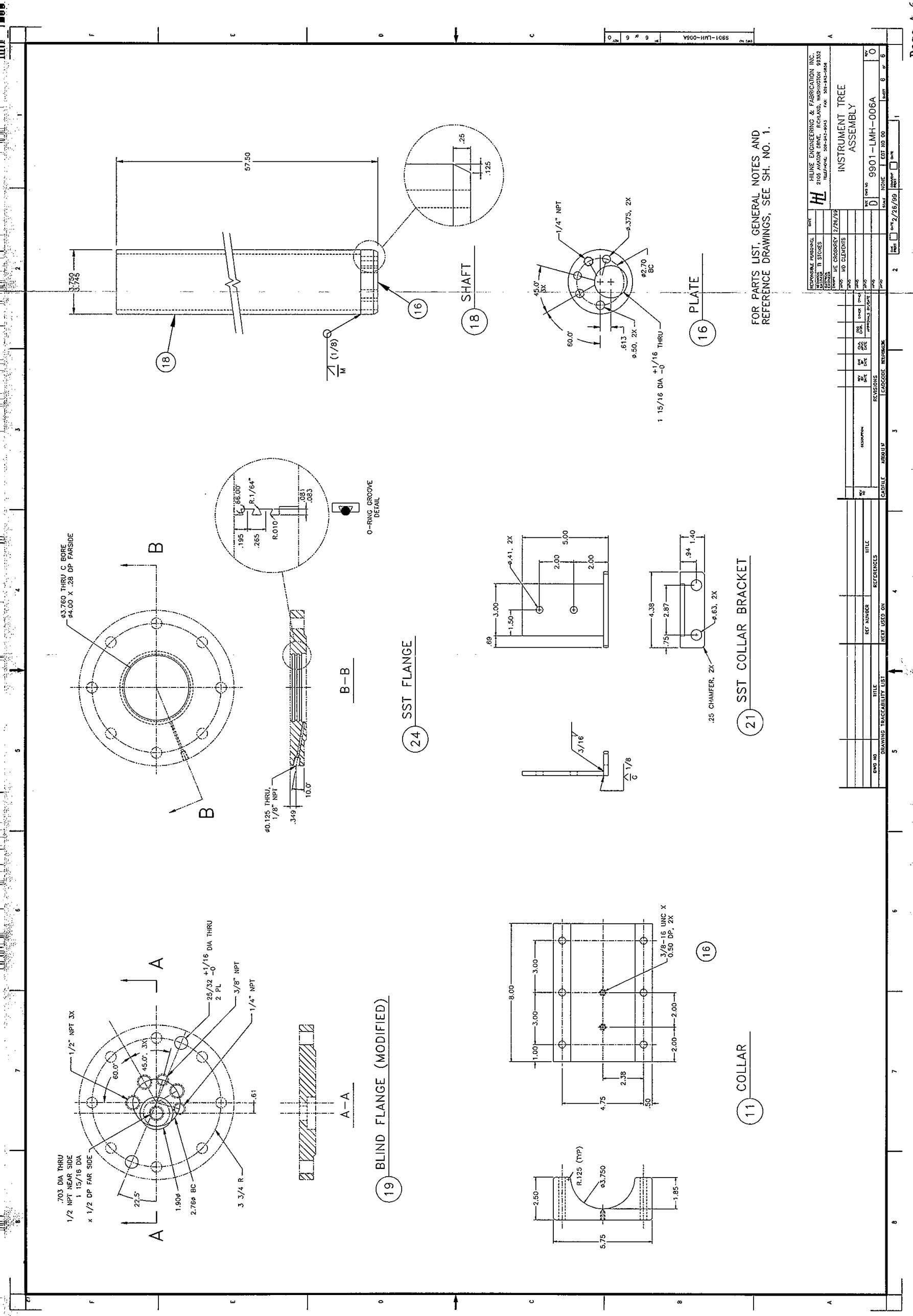

